\title{
Explaining the pattern of Russian authoritarian diffusion in Armenia
}

\section{Abstract}

The literature dealing with the international dimensions of authoritarianism suggests that regional hegemons may exploit linkage and leverage to counter democracy and diffuse authoritarian ideas and practices. However, there is a need for more research on whether authoritarian diffusion is actually happening, including the circumstances under which linkage and leverage are translated (or not) into policy convergence. This article addresses these shortcomings by examining the high-value case of Armenia - a country with growing levels of dependence on Russia following its rejection of the EU's Association Agreement in 2013 and accession to the Russian-led Eurasian Economic Union in 2015. Drawing on a combination of original elite and expert interviews this article argues that although there is evidence of Russian authoritarian diffusion, there is limited evidence of policy convergence. Instead, material incentives and concerns over legitimacy continue to privilege democratic norms and make the costs of Russian-style restrictive legislation prohibitive for incumbents.

Key Words: Russia; Armenia; authoritarian; diffusion, agency; NGOs

Sean Roberts, University of Portsmouth

Ulrike Ziemer, University of Winchester 


\section{Introduction}

The last decade has seen increasing scholarly focus on the international dimensions of authoritarianism and the way negative external actors or 'black nights' exploit asymmetric relations, including linkage and leverage to counter democracy and diffuse authoritarian ideas and practices. In particular, Russia has been named as one of the key suspects, possessing both the means and the motives to influence regional political systems, either bilaterally or through authoritarian multi-lateral organisations (Ambrosio 2008; Bader, Grävingholt and Kästner 2010; Jackson 2010; Koesel and Bunce 2013; Tansey 2016; Von Soest 2015). With the backdrop of the Ukraine crisis and hard competition between Russia and the West, and with an emerging global trend of declining political rights and civil liberties, the international dimensions of authoritarianism looks set to remain a salient research topic. ${ }^{i}$

However, the current research agenda is not without its limitations. The almost exclusive focus on the structural aspects of authoritarian influence has resulted in the under-elaboration of important agency considerations - a point noted by a growing number of scholars (Jackson 2010; Koesel and Bunce 2013, 753; Tansey 2016; Tolstrup 2013). In particular, there is a need for more research on whether authoritarian diffusion is actually happening (Ambrosio 2010, 388), but also the circumstances under which linkage and leverage are translated (or not) into policy convergence.

In order to address these shortcomings, this article utilises the high-value case of Armenia - a small, landlocked state located in the strategically important South Caucasus, whose preexisting, high-levels of dependence on Russia have increased following a largely unexpected foreign policy U-turn that saw Armenia abandon its long-stated plan to sign an EU Association Agreement in September 2013 and instead join Russia's Eurasian Economic Union in January 2015. As discussed below, the combination of Russia's growing linkage and leverage together with high-level statements by Russian officials highlighting Armenia's 'problematic' civil society, create theoretically ideal conditions to expect strong evidence of authoritarian diffusion from Russia to Armenia.

As the covert nature of authoritarian influences has been flagged as a methodological problem (Tolstrup 2015a), this article utilises elite and expert interviews to complement primary and secondary sources. As such, this article draws on 28 semi-structured interviews with Armenian politicians, Armenia-based experts, journalists and NGO representatives, conducted by the authors in 2014 and 2016 and follow-up correspondence in early 2017 (see 
appendix 1 for a full list of interviewees). The drawbacks of this research design, in particular the problem of bias (Green and Kohl 2007, 159) were mitigated by triangulating statements from interviewees with other sources and by conducting a greater number of interviews to allow data to be drawn from a larger sample. ${ }^{\text {ii }}$ The time frame for this research includes the period from September 2013, following Armenia's decision to abandon the EU's Association Agreement, up to the parliamentary election in April 2017.

This article proceeds as follows. The first section defines authoritarian diffusion and considers the means and motives behind Russia's efforts to counter democracy in the region. The second section considers evidence of authoritarian diffusion, including the transfer of Russia's own restrictive legislation to Armenia. The final section considers explanations for the pattern of authoritarian diffusion seen in Armenia, including the role of national policy makers, who in the case of Armenia are pulled between competing Russian, EU and US influences. This final section utilises the competing 'logics' of appropriateness and consequences as a framework to understand the traction of authoritarian and democratic ideas and practices in Armenia.

In sum, this article presents two substantive lines of argumentation. First, there is evidence of authoritarian diffusion from Russia to Armenia, in particular the diffusion of ideas and practices aimed at restricting gay rights and non-traditional gender relations, as well as the activities of civil society in general. However, there remains limited evidence of policy convergence in key areas, such as NGO and electoral legislation - despite the fact that both were subject to major amendments following Armenia's accession to the Eurasian Economic Union in 2015. Second, despite high-levels of Russian linkage and leverage, material incentives and concerns over legitimacy continue to privilege democratic norms and make the costs of Russian-style legislation prohibitive for incumbents. The implication is that, despite the limited embeddedness of democracy in much of the post-Soviet space, including Armenia, democracy promotion is effective in countering authoritarian diffusion, meaning continued Western support is essential for negating the spread of counter-democratic influences.

\section{Means, motives and Russian authoritarian diffusion}

This section reviews existing literature on authoritarian diffusion in order to understand how it is theorised to occur, but also the motives behind it. In both cases, the discussion focuses on Russia and Armenia, providing a framework for the empirical sections that follow and an $a$ 
priori justification for expecting strong evidence of authoritarian diffusion from Russia to Armenia in the period in question. As discussed below, Russia has both the means and the motives to diffuse authoritarian ideas and practices in Armenia, in particular following the latter's decision to reject the EU's Association Agreement in 2013 and join the Eurasian Economic Union in 2015, alongside Belarus, Kazakhstan, Kyrgyzstan and Russia.

\section{The process of authoritarian diffusion}

For the purposes of this article, diffusion is defined as 'the transfer among countries of an innovative idea, product, policy, institution or repertoire of behaviours' (Koesel and Bunce 2013, 753) - in short: the transfer of ideas and practices. As such, authoritarian diffusion is defined as the transfer of authoritarian ideas and practices, which can be usefully (but not exclusively) summarised as activities aimed at bypassing legislatures, restricting the ability of opposition parties to operate, restricting political and civil rights and politicising the judiciary (Skene 2003, 190). As discussed in the next section, authoritarian ideas and practices aimed at restricting political and civil rights (rights that ensure participation in political and civic life without discrimination or repression) are particularly relevant for the case in question.

In terms of the mechanisms behind authoritarian diffusion, there is some dispute surrounding the level of intentionality, or the extent to which authoritarian ideas and practices are 'imposed' as opposed to 'adopted' (Ambrosio 2010, 378). The position taken in this article is that authoritarian transfers are both active and passive in nature, with diffusion pressures being coercive (hierarchical authority relations), as well as mimetic (inferential shortcuts) and normative (legitimate and reputable) and often working together simultaneously (Gel'man and Lankin 2008, 45). As detailed, the Putin regime's willingness to promote authoritarian ideas and practices, together with the high-levels of linkage and leverage Russia enjoys in the region (see below), make both active and passive authoritarian diffusion possibilities to consider.

This acknowledgement of active and passive mechanisms supporting diffusion finds resonance in existing literature on the international dimensions of authoritarianism, but also the analogous literature on democratic diffusion, both by individual state actors (e.g. the US) and supranational actors (e.g. the EU). The process of Europeanisation, for example, understood as the export of forms of political organisation and governance beyond the European territory (Olsen 2002, 925) is facilitated by a combination of active and passive mechanisms. The latter includes the deliberate conditionality of the pre-accession process and 
the former the 'attraction' of EU membership (Vachudova 2005, 63) or what Manners terms the EU's power of 'example' and its ability to shape conceptions of 'normal' to outside actors (2002, 239).

Following from this, studies have attempted to understand the international dimensions of authoritarianism, if not actual diffusion processes, by utilising similar active and passive frameworks (Tolstrup 2013, 718). Bader, Grävingholt and Kästner (2010, 84), for example, identify two types of mechanism stabilising non-democratic rule: the power of example and the power of influence. Tansey (2016) creates a typology containing three categories of international influences on domestic politics, including passive; unintended influences; and what he terms 'international autocratic sponsorship' or an external actor's intentional assistance to help autocratic elites gain or maintain political power (Tansey 2016, 15). Elsewhere, passive mechanisms have been identified with increasing economic and financial ties and diplomatic support for a particular regime, and active mechanisms with deliberate actions taken to undermine another country's liberal performance and to strengthen the survival capacity of incumbents (Yakouchyk 2016, 200).

In terms of the potential for ideas and practices to diffuse from one state to another either actively or passively, the linkage and leverage framework developed by Levitsky and Way (2010) remains influential. Linkage is a multidimensional concept that refers to networks of interdependence that connect states, economies and societies (Levitsky and Way 2010, 43). Leverage, in contrast, refers to a state's bargaining power vis-à-vis other international actors, as well as its ability to resist punitive measures. As Levitsky and Way note: leverage does not refer to the exercise of power per se, but to a state's overall vulnerability to external pressure (Levitsky and Way 2010, 41). Taken together, levels of linkage and leverage provide a nuanced, structural framework to approach the subject of authoritarian diffusion, and as discussed below, provide the theoretical 'means' through which Russian influence may translate into diffusion.

Indeed, the literature has increasingly highlighted Russia's favourable 'asymmetry of power' in the region as a source of control over neighbouring countries (Cameron and Orenstein 2012) and nowhere is this more evident than in the case of Armenia. Armenia has been described as 'over-dependent' on Russia, with the latter exerting 'serious' power and influence over Armenian politics and society (Giragosyan 2013, 12). Russia is also considered to possess significant hard and soft power resources when it comes to Armenia, 
constituting an 'incomparable pole of attraction' vis-à-vis the EU (Loda 2017, 2). While soft power resources should not be underestimated, in particular the role of cultural organisations that promote bilateral relations (see the next section), it is in the economic and security spheres that the extent of Russian linkage and leverage becomes apparent.

In terms of economic relations, Russia is Armenia's main trading partner and main source of foreign direct investment (Vasilyan 2017, 35-37). In addition, and in recent years, the Russian state has been effective in increasing its economic leverage through asset swaps in return for debt write-offs. Between 2002 and 2009, Russian companies acquired assets ranging from the country's largest cement factory to the Armenian rail network in return for debt cancellation and significant Russian investment (German 2012, 99). From 2006, and in part payment for debts accrued, Armenia also gave near full control of its energy system to Russia via Gazprom (Sasse 2013, 572) and Russian energy, in particular gas supply, remains a key component of Armenia's dependence. Russia is also home to the world's largest Armenian diaspora. In 2015, the World Bank estimated that just over 14 per cent of Armenia's GDP came from personal remittances sent by Armenians working abroad (World Bank 2015), with over 700 million USD transferred to Armenia in 2016 by individuals working in Russia (Bank of Russia 2016).

Alongside economic leverage, security linkage and leverage also comprise a significant aspect of the Armenia-Russia relationship. Armenia is a member of the Russian-led Collective Security Treaty Organisation (CSTO), while a bilateral treaty on Friendship, Cooperation and Mutual Assistance, which includes a military mutual assistance clause, was signed by Yerevan and Moscow in 1997. In the context of hostile relations with neighbouring Azerbaijan over the disputed Nagorno-Karabakh territory, Russia's continuing supply of military hardware, but also the former's military presence is of paramount importance for Armenian security. The Russian $102^{\text {nd }}$ Military Base is located in the Armenian city of Gyumri, while the Russian $3624^{\text {th }}$ airbase is located at Erebuni Airport, near Yerevan. Russian troops also patrol both the Armenia-Iran and Armenia-Turkey borders and in 2015 Russia granted Armenia a 200 million USD loan to help modernise its armed forces (Mkrtchyan 2015).

In fact, the reliance on Russian security offers an explanation as to why Armenia eschewed the EU's Association Agreement in 2013 in favour of Eurasian economic integration, in what was a considered a surprise foreign policy U-turn. It later transpired that this decision was 
based on a 'rational security logic', with Armenian President, Serzh Sargsyan, indicating that membership of Russian-led security structures made it unfeasible to opt-out of the associated economic space (RFE/RL 2016), paving the way for Armenia's eventual membership of the Eurasian Economic Union in January 2015.

\section{The motives behind Russia's support for autocracy}

In terms of the motives behind the support and promotion of autocracy, it is the regional level that currently provides the strongest rationale and the best understanding of Russia's goals. Existing studies suggest that democratic change in any given region increases the pressure on authoritarian regimes for similar change (Pevehouse 2002). As a country's regime tends to resemble that of their neighbours (Brinks and Coppedge 2006; Von Soest 2015, 631), Russia is seen to have a vested interest in preventing the further spread of democratising influences in order to shield its own domestic politics (Tansey 2016, 2).

There is also an acknowledgment that Russia's economic and security interests provide an additional rationale for promoting and supporting autocracy in the region (Yakouchyk 2016, 200). The diffusion of democratic ideas and practices increases the prospects of regime change in Russia's partner states which, in turn, increases the prospect of new leaders revising existing economic and security arrangements with Moscow. Russian autocracy promotion may help stabilise pro-Moscow regimes (e.g. through direct or indirect financial support), but as discussed in the next section, targeted information campaigns may also work on a societal-level by framing democracy as a threat to political stability and 'traditional values' in target countries, undermining public support for closer alignment with the West (e.g. the signing EU Association Agreements) and for leaving Russia's sphere of influence.

Overall, there is a clear rationale behind Russia's efforts to counter democracy in post-Soviet space. As Ambrosio aptly summarises; authoritarian regimes are not static targets for democratic diffusion, but employ active strategies, both to preserve their own political systems and to 'reinforce like-minded countries' and undermine politically dissimilar ones (Ambrosio 2008, 1325). Moreover, there are strong indications that Russia is indeed promoting the diffusion of aspects of its own political system in neighbouring states.

In 2005, the head of the Federal Security Service (FSB), Nikolai Patrushev, stated that Russia was interested in unifying NGO legislation in CIS countries to prevent the spread of 'colour revolution' (Jackson 2010, 105). The colour revolution phenomenon that swept incumbents 
from power in Georgia, Ukraine and Kyrgyzstan saw a prominent role for NGOs in mobilising protestors (Ambrosio 2007, 238; Finkel and Brudny 2012), leading the Russian authorities to amend their own legislation in 2006. Aside from regulating funding for NGOs, these amendments signalled the start of an 'import substitution' strategy, in which foreignfunded NGOs would be gradually replaced by more compliant organisations financed directly by the Russian state (Henderson 2010, 255). In 2012, following widespread protests at electoral fraud, the Russian authorities introduced a controversial 'foreign agent' law, creating a special category of NGOs in receipt of foreign financial support and engaged in 'political activity'.

In what was seen as an ominous development for Armenian civil society, the Russian ambassador, Ivan Volynkin, gave an interview in May 2014 in which he identified Westernfunded NGOs as a threat to bilateral relations, calling for them to be 'neutralised' through information campaigns and other methods (Volynkin 2014). These methods included legal moves to regulate the activities of NGOs, in what was widely interpreted as a call for Armenia to adopt Russian-style legislation. These comments were supported in February 2015 by the Head of the Russian Federation Council's International Committee, Konstantin Kosachev. Aside from expressing dissatisfaction with the work of the Armenian NGO sector, he also claimed that around 350 Armenian NGOs were actively agitating against Eurasian integration in favour of the EU (RIA Novosti 2015).

This diplomatic pressure is understandable in the context of Armenia's relatively free civil society in comparison with other members of the Russian-led Eurasian Economic Union. Armenia's civil society has benefited from consistent Western funding, including EU support in the form of the Partnership and Cooperation agreement (1999) and the Armenia-EU Action Plan (2006) - both of which included a mutual commitment to develop political and civil rights and NGOs. In 2012, just before the rejection of the EU's Association Agreement, Armenia ranked $53^{\text {rd }}$ on the comparative Human Freedom and Democracy Index, compared to Russia's rank of $111^{\text {th }}$ (Vásquez and Porčnik 2016).

As outlined in the next section, Russia's increasing influence within Armenia since 2013 has coincided with the opening of several 'policy windows', including the adoption of a new constitution (2015), electoral code (2016) and, importantly, amendments to existing NGO legislation (2017), creating unprecedented opportunities for Russia to push for policy 
convergence. In addition, there is evidence that Russian-inspired diffusion in this sector has already happened.

In 2008, Armenia's president, Serzh Sargsyan, ordered the creation of a Public Council to mediate between the state and civil society, based on the analogous Russian Public Chamber established in 2006. The Russian Public Chamber, which was also diffused to neighbouring Kazakhstan in 2007, was intended as a non-partisan oversight committee, but essentially formed an extra layer of state control over civil society (Roberts 2015, 151). In 2012, in yet another ominous development, the Armenian Public Council produced a concept paper which included a number of controversial suggestions for regulating NGO financing (Borshchevskaya 2013) raising the prospect that the government favoured a Russian-style 'foreign agent' law.

\section{Evidence of authoritarian diffusion}

In order to facilitate analysis, this section is divided into two parts. The first part presents a general discussion of the situation in Armenia following the decision to reject the EU's Association Agreement in 2013. This part provides important context and considers evidence of both the promotion of authoritarian ideas and practices and their diffusion from Russia to Armenia. The second part then considers the strongest evidence of all - policy convergence in the form of Armenia's amended NGO law (Law on Public Organisations), as well as other key legislation adopted in the post-2013 period.

\section{The general situation in Armenia}

In line with the framework presented in the previous section, it is possible to outline three areas where authoritarian promotion and diffusion are evident. The first relates to the deteriorating human rights situation in the country, with an indirect link to Russia. The second relates to the promotion of ideas (NGOs as a 'fifth column') through Russianlanguage media, undermining the reputation of pro-democracy organisations. The third, related area is the diffusion of so-called 'parent committees' to Armenia from Russia in what appears a coordinated campaign directed at mobilising opponents of gay rights and nontraditional gender relations. While 'traditional values' and even homophobic attitudes are widespread in Armenia (see final section), the diffusion of parent committees reveals a direct link to Russia. 
First, and in terms of the human rights situation, there is perception in some quarters that the Armenian authorities are increasingly adopting the kind of responses to dissent and political protest often employed by the Russian state. This deteriorating human rights situation is only indirectly related to both diffusion and the period following September 2013, and is better understood as a longer-term problem in Armenia, in particular following the 2008 presidential election when protests at electoral fraud were violently dispersed by the security services. However, the human rights situation has become strained since 2013, in particular following the spike in hostilities between Armenia and Azerbaijan over the disputed Nagorno-Karabakh region in 2016.

In April 2016, the frozen conflict in Nagorno-Karabakh temporarily thawed in what came to be known as the 'Four Day War' resulting in around 200 Armenian combatants killed and wounded and a loss of territory previously controlled by the military. ${ }^{i i i}$ The conflict in Nagorno-Karabakh has been a defining feature of Armenian politics ever since the vote to unify the region with Armenia in February 1988. Not only has the conflict shaped Armenia's post-Soviet 'war economy', but it continues to strongly influence the country's political leadership. Armenia's first president, Levon Ter-Petrosyan, was forced to resign in 1998 following pressure from the influential network of politicians and Karabakh war veterans opposed to his compromise settlement with Azerbaijan (Hale 2015, 228). Armenia's subsequent presidents, Robert Kocharyan (1998-2008) and Serzh Sargsyan (2008-present) were both born in Nagorno-Karabakh and together head the informal 'Karabakh clan'.

For this reason, the renewed hostilities in April 2016 were significant, in particular the events occurring in the immediate aftermath. In July 2016, 20 armed Karabakh war veterans calling themselves 'Sasna Tsrer' (Daredevils of Sassoun) seized control of a police station in Yerevan, taking several hostages. ${ }^{\text {iv }}$ Their demands included the release of political prisoners but also the resignation of President, Serzh Sargsyan, accusing the authorities of endangering national security (Ishkanian 2016). The hostage takers reportedly framed their actions as a national liberation movement against Russian colonialism, suggesting that the current Armenian leadership was being directly controlled by Moscow (Demytrie 2016). There were also rumours at the time that Russian Special Forces had arrived to help break the crisis, before the eventual surrender of the hostage takers (Zolyan 2016).

The two-week hostage crisis also saw sizeable anti-government protests. In the period 17-30 July, approximately 700 civilians were detained without grounds and around 100 people 
hospitalized (Ioannisyan 2016) in what was considered a particularly hard police response. This event, together with the official response to earlier protests at energy price rises in June 2015 ('Electric Yerevan') and a notable increase in police violence directed against journalists in the period 2014-2016 (Barseghyan 2016) led some to suspect that Armenia's foreign policy U-turn had emboldened the authorities or as one interviewee noted; 'the foreign policy U-turn affected police behaviour and their performance' (Interview, Sona Ayrazyan, 2016).

In contrast, Russian media framed the July 2016 events in terms of a Western-backed attempt at regime change, with prominent Russia-funded media outlets, such as Sputnik Armenia, noting the role of Western-backed NGOs in organising the protests (Sputnik Armenia 2016). This relates to the second area of interest - Russia's state-led information campaign targeting pro-democracy NGOs. In January 2014, it emerged that the head of the Russian International News Agency RT (Russia Today), Dmitry Kiselov, had established a discussion club in Yerevan (the Gribeyedov Club) and was making regular visits for closed-door meetings with its pro-Russia members (Ghahriyan 2014). Kiselov, who was appointed by Putin to head $R T$ in December 2013 is considered Russia's chief propagandist raising concerns that Moscow was ramping up its media campaign, and that Kiselov was personally attempting to formulate an information strategy to weaken democratic influences in Armenia. In 2016, a content analysis of Russian-funded media highlighted the characteristics of Moscow's information campaign in several Eastern Partnership states, including Armenia. This research, produced with the assistance of the Yerevan Press Club, monitored a number of Russian-language media outlets, including the Novoye vremya newspaper and the online news sites Iravunk and Sputnik Armenia. The findings showed that Russian language propaganda was dynamic, adapting to the audience of the country in question, and that in Armenia's case approximately one third of the messages coded (105 out of 370 references) implied that Armenian civil society (NGOs) was a 'fifth column' of the West (Eap monitoring 2016).

This theme of fifth column has been a consistent one in the Russian-language media in Armenia. For example, in August 2016, a Russian language blog, using the pseudonym 'Armenian News' was posted on the popular LiveJournal platform, making serious accusations against a number of prominent NGO workers and opposition politicians. The individuals in question were accused of collusion with the United States and of attempting to 
'destroy the country' - their photographs and details were included in the blog post (Novosti Armenia 2016). Likewise, during the April 2017 parliamentary election, Twitter saw a wave of automated tweets of Russian origin aimed at the campaign feed (\#armvote17). Messages included 'American money to fund post-electoral protests in Armenia' and 'NGOs will be trying to disturb the elections in Armenia' (Vardanyan 2017). As one interviewee noted:

Periodically, Russia does something against us, that is, against me, against my NGO [The Helsinki Assembly], some sort of Soviet-style propaganda, like the LiveJournal incident, or propaganda directed against us via the Armenian diaspora in Russia (Interview, Artur Sakunts, 2016).

The third area relating to authoritarian diffusion concerns the attempt by groups within Armenia to mobilise opponents of gay rights and non-traditional gender relations. In fact, these attempts were evident prior to September 2013 and were also connected to Russian efforts at stigmatising both the EU and Western-funded NGOs in the run-up to the Vilnius summit in November 2013, when Armenia was expected to sign an Association Agreement with the EU. Russian-language media was consistently suggesting that the Association Agreement would result in same-sex marriage, gay-parades but also the legalisation of incest and paedophilia and other 'progressive norms' that would split Armenian society. ${ }^{\mathrm{v}}$ In short, elements of the Russian-language media claimed that any decision to sign an Association Agreement with the EU would result in 'a flood of homosexuals coming from Europe' (Interview, Anjela Khachaturian, 2016).

This campaign acquired unusual significance with the passage of legislation that further increased the salience of the sexual minority issue. In May 2013, so-called Law 57 was passed by the Armenian parliament, guaranteeing equal rights for men and women, but containing a controversial clause that defined gender as the 'acquired, socially fixed behaviour of persons of different sexes' (Martirosyan 2013). This clause was interpreted in some quarters as a threat to Armenia's traditional values, sparking a significant mobilisation among conservative groups opposed to this law, but also among Russia supporters who saw an opportunity to oppose Armenia's planned Association Agreement.

One such group was the Pan-Armenian Parents Committee (PPC), formed in 2013 in the aftermath of Law 57 to defend family and traditional values, in particular at the legislative level. The PPC actually traces its origins to another organisation - the Yerevan Geopolitical Club - a Russian-language virtual platform for disseminating analytical articles critical of 
Western democracy (Nikoghosyan 2016). Arman Boshyan, who heads both, formed the PPC in July 2013 following a meeting of the Yerevan Geopolitical Club, with the two organisations sharing the same Russian language website. But, as the Director of the Center for Gender and Leadership Studies in Yerevan notes, the reach of the PPC extended beyond online campaigning:

It all began in 2013, when Armenia was about to sign the EU's Association Agreement. They [the PPC] even had the resources to take their campaign on TV. If they'd stayed on social media they would have been less effective, but on TV...even educated people started to question our work (Interview, Gohar Shahnazarian, 2016).

The Armenian PPC appears to be a case of authoritarian diffusion, appearing almost identical to its Russian equivalent - the All-Russian Parent Resistance movement - an organisation with close connections to the Russian state. This pro-Putin organisation held its founding conference as a registered NGO in February 2013 (Putin attended in person) although it traces its origins to a societal movement that was mobilised to oppose legislative proposals under consideration by the Russian parliament in 2012 (APR 2017).

The leader of the All-Russian Parent Resistance, Mariya Mamikonyan, is married to Sergei Kurginyan, an ethnic Armenian and well-known political figure, who leads the patriotic 'Essence of Time' movement which featured in several pro-Putin rallies in 2012. Kurginyan has close contacts with the Armenian PPC and has been instrumental in promoting the Russian state's interests in the post-Soviet space and Europe. The broader significance of the All-Russian Parent Resistance is that similar organisations began to appear at roughly the same time, not only in Armenia, but in other post-Soviet states intending on signing Association Agreements with the EU, including Georgia, Moldova and Ukraine, with evidence that their public announcements were timed with press-conferences held by the AllRussian Parent Resistance (Babayan 2015).

In addition to the PPC and Sergei Kurginyan, there are a number of other organisations and individuals extending Russian linkage and leverage over domestic politics in Armenia. In February 2016, the Armenian Revival Union was established, uniting 12 political parties and 138 NGOs under the leadership of Artur Baghdasaryan - a figure who sits on the board of two Russian corporations (Bank Sistema and Rosneft) and who is financially supported by Russian-Armenian businessman, Ara Abrahamyan (Novikova 2017, 11-12). Abrahamyan is also the president of the Union of Armenians in Russia, which is the major organisation 
representing the Armenian diaspora and which openly supports Eurasian economic integration and closer ties with Russia.

\section{Policy convergence and authoritarian diffusion}

In terms of policy convergence and in particular the diffusion of legislation, there is some evidence of Russian influence, although this is mostly limited to blocking proposed laws. For example, an attempt by the Armenian Parliament to pass legislation aimed at preventing domestic violence was dropped in the face of strong resistance, in particular from organisations with close ties to Russia. The proposed law, supported by the EU, was withdrawn by the Justice Ministry in February 2017 following a public outcry. Analysis indicated that the main opponents of this law were either pro-Russian or in receipt of Russian funding, including the PPC and the Yerevan Geopolitical club, as well as a number of other organisations (Epress.am 2016a). In Russia, Vladimir Putin signed controversial amendments decriminalising some forms of domestic violence in February 2017.

However, in terms of the other, major legislative projects in Armenia, in particular those affecting the political system as a whole, evidence of diffusion is largely absent - despite concerns that Russia would try to exploit opening 'policy windows'. This was definitely the case with proposed NGO legislation, in view of the high-level statements made by Russian officials on this 'problematic sector', with fears that 'Russia will take the opportunity to impose a restrictive law in line with their own example' (Interview, Mikael Hovhannisyan, 2016).

As mentioned, the Russian example emerged from the mid-2000s amid growing concerns that Western-funded NGOs were a common denominator in the wave of colour revolutions sweeping the region, 1999-2005. As a result, Russian law-makers amended the Law on Public Associations in 2006, introducing new reporting measures and strict auditing, as well as increasing the scope for the Justice Ministry to liquidate NGOs in breach of them. This process of restricting NGOs received renewed impetus in 2012 in the wake of large-scale protests that swept the country following the December 2011 parliamentary election. The additional amendments made in July 2012 included the so-called 'foreign agent' law which created a special category of NGOs in receipt of foreign financial support and engaged in political activity. The term 'foreign agent' carries a pejorative and synonymous meaning of 'foreign spy', serving to stigmatise the activities of these NGOs. 
Surprisingly, and in terms of Armenian legislation, no Russian-inspired diffusion was evident when the new NGO law came into force in February 2017. In sum, the new amendments contain three substantive changes. The first change is that NGOs can provide services and receive profit. This was viewed as a major innovation and gives NGOs the right to engage in business activities. The second is that Armenian NGOs in receipt of state funding are required to have an external audit. Although there was an attempt to extend this to all NGOs, this did not find its way into the final draft. Finally, under the auspices of the new legislation, NGOs have the right to appeal to the courts on issues relating to the public interest, but only on environmental issues.

Armenia's new NGO legislation, as well as the government's overall approach, was largely given a positive evaluation by the sector (Interview, Sona Ayrazyan, 2016). Although there are outstanding issues, such as the scope and ability of NGOs to refer to the courts in order to protect the public interest, the ability of NGOs to gain financial independence through revenue-generating activities was seen as an improvement on existing legislation. Despite the tendency to require more accountability and reporting from NGOs, 'the term 'foreign agent' or anything similar is nowhere in the law' (Personal correspondence Artur Sakunts 2017).

In the final analysis, Armenia's decisions to reject the EU's Association Agreement in 2013 and join the Eurasian Economic Union in 2015 have increased Russian influence in the country. As detailed in the previous section, there is evidence that Russia has promoted autocracy through a combination of information campaigns and coordination with proRussian organisations and individuals, and that some authoritarian diffusion has occurred. But, in the post-2013 period, there is little evidence that Russia has directly impacted civil laws, despite the opportunity of several important policy windows. This is certainly the case with the NGO law, but also other key legislation in this period.

For example, the process of amending the Armenian Constitution (initiated by Presidential Decree on 4 September 2013 - the day after Serzh Sargsyan announced that Armenia would not sign the EU's Association Agreement) saw Armenia eventually switch from a presidential to a parliamentary republic following a constitutional referendum in December 2015. But, despite concerns with a number of the articles and despite domestic opposition to the constitutional changes, the Council of Europe's Venice Commission praised the document and considered the amendments in line with international standards of democracy (Council of Europe 2015). 
Likewise, the new electoral code adopted in May 2016 was considered controversial among segments of the public and contained a number of restrictions on election observers, but was signed-off by all the political parties represented in the Armenian parliament, again receiving a positive conclusion by the Venice Commission. Electoral reform has been noted as one of several authoritarian strategies designed to weaken opposition and to bolster incumbents (Finkel and Brudny 2012, 17) and a key area that Russia has targeted to shore up preferred regimes in other countries (Tolstrup 2015b; Bader 2015, 1353, 1366).

\section{Explaining the pattern of Russian authoritarian diffusion in Armenia}

The aim of this article is to assess if authoritarian diffusion is happening, but also the circumstances under which linkage and leverage are translated (or not) into policy convergence. These aims relate to the growing acknowledgement that agency considerations are under-elaborated in current research on the international dimensions of authoritarian rule (Jackson 2010; Koesel and Bunce 2013, 753; Tansey 2016; Tolstrup 2013). As Tolstrup notes; the focus on structure, such as geographical proximity, interdependence and power asymmetries often renders frameworks unable to explain anomalies or cases that do not seem to fit the pattern (Tolstrup 2013, 717).

Armenia, it seems, is one such anomaly. As argued, there is evidence that authoritarian ideas and practices aimed at restricting political and civil rights, including undermining prodemocracy NGOs and mobilising opponents of gay rights and non-traditional gender relations have been promoted and diffused from Russia to Armenia. However, there remains limited evidence of policy convergence in key areas, such as NGO and electoral legislation despite Russia's undoubted 'means and motives' to diffuse its own restrictive legislation. How can we explain why linkage and leverage did not translate into policy convergence?

\section{The adoption of authoritarian ideas and practices}

In order to explain the pattern of Russian authoritarian diffusion in Armenia it is necessary to consider the role of 'adopters' alongside that of the 'promoters' of ideas and practices. This includes acknowledging the role of 'gatekeeper elites' (Tolstrup 2013), who in the case of Armenia are pulled between competing external actors, including Russia, the EU and the US. The choice here is to utilise the extant literature dealing with norm adoption. As detailed below, the competing 'logic of consequences' and 'logic of appropriateness' provide a clear framework for exploring domestic and international diffusion pressures and the way they influence policy and policy makers. But more importantly, and in view of Armenia's 
exposure to democratic diffusion, this framework is able to explore one obvious explanation for the pattern of authoritarian diffusion evident - the counter-balancing role of democratic norms.

A norm is understood as an inter-subjective or shared understanding of standards of behaviour, as either good or bad (Klotz 1999, 14). The process by which norms emerge in national settings is typically theorised in either rationalist or interpretivist terms or through the competing logic of consequences and logic of appropriateness, although differences between these two logics are open to debate (Barkin 2010; March and Olsen 1989, 162).

The logic of appropriateness is also understood as a process of socialization when an agent switches from following the logic of consequences or 'conscious instrumental calculation' to conscious role playing (Checkel 2007, 6). In other words, norms become internalised by actors, exerting either bottom-up influence through societal mobilisation and pressure on elites or top-down influence, as elite decision-makers gradually internalise inter-subjective understandings (Checkel 2001, 57).

As an explanation for the limited policy convergence with Russia, appropriateness or democratic socialisation, does have some 'logic'. Armenia has enjoyed a relatively longstanding relationship with Western actors, notably the EU and US, meaning the elite and public have experienced sustained exposure to democratising influences and democratic norms. As mentioned, the EU and Armenia signed a Partnership and Cooperation agreement in 1999 and an Action Plan in 2006. By the mid-2000s, it was noted by some experts that in certain areas Armenia had achieved more success in implementing its Action Plan than both Georgia and Azerbaijan (Minasian 2005, 27), making it a reform leader in the South Caucasus.

However, the overall effectiveness of Western democracy promotion in Armenia has been questioned, with no shortage of criticism surrounding the vagueness of EU programmes and EU inconsistency (Smith 2005, 764-5). In addition, the absence of any realistic prospect of EU membership for Eastern European Neighbourhood Policy countries is seen as a serious hindrance to democracy promotion efforts (Chryssogelos 2017, 260). Time series opinionpoll data appears to confirm the lack of 'embeddedness' of democratic norms in Armenia, showing falling support for democracy, 2011-2015, with responses to the question 'democracy is preferable to any other kind of government' dropping from 55 per cent in 2011 
to 36 per cent in 2015 (Caucasusbarometer 2015). As detailed below, there is little evidence that democratic norms have 'socialised' the ruling elite either.

Rather, it is the logic of consequences that offers the best explanation for the pattern of authoritarian diffusion seen in Armenia since 2013. Norm adoption, as viewed from the logic of consequences is driven by actor preferences and expectations and a general attempt to make outcomes meet subjective desires (March and Olsen 1989, 160). Actors adopt and reject norms based on their anticipated utility, with external actors (typically state actors) conditioning this utility through sanctions and incentives.

Despite the fact that Armenia declined to sign an Association Agreement in 2013, the EU and US continue to provide significant financial support. The US, for example, remains one of the biggest contributors of aid to Armenia, despite recent funding cuts (the Armenian branch of USA's National Democratic Institute was closed in 2015). Out of the five countries offered EU European Neighbourhood Policy Action Plans (Armenia, Azerbaijan, Georgia, Moldova and Ukraine), Armenia received the second highest amount of USAID (on a per capita basis) for the period 1998-2007 (24.7 USD), trailing only Georgia's 51.57 USD (Sasse 2013, 558). In 2016, the US delivered over 9 million USD in humanitarian aid to Armenia, while organisations based in the US, such as the National Endowment for Democracy funded over $20 \mathrm{NGO}$ and media initiatives in the country.

The EU has also had a long-term financial impact in Armenia. The EU's TACIS programme (Technical Assistance to the Commonwealth of Independent States) which ran from 1991 until 2007, before being replaced by the European Neighbourhood Policy, allocated significant funding for Armenia. In the period, 2004-2006, Armenia received 20 million euros from TACIS (Tacis 2003). In September 2015, Armenia and the Council of Europe adopted a new Action Plan for the period 2015-2018 to improve democracy, human rights and the rule of law. Funding for these projects comes from multiple sources, including the EU's Eastern Partnership, and totals more than 16 million euros (Council of Europe 2016). The EU and Armenia also concluded a planned EU-Armenia Comprehensive and Enhanced Partnership Agreement in 2017 designed to 'expand relations' (Armenianweekly 2017).

In fact, much of the new legislation adopted by Armenia, in particular the new electoral code, was conditioned on EU aid, giving power-holders a clear incentive to work closely with the EU and associated bodies to pass acceptable legislation. Although Russia possesses both the resources and agencies capable of lobbying the country's wider interests (Lough et al. 2014, 
in the case of Armenia, there is a perceived lack of commitment: 'Russia is trying to build influence. In 2013, Parent's Committees were simultaneously established in Russia, Georgia, Ukraine and Armenia ... but they don't have money to support campaigns directly'. (Interview, David Armeniyan, 2016).

However, material incentives do not fully account for the pattern of authoritarian diffusion seen in Armenia. While they offer a potential explanation for the absence of Russian-style restrictive NGO and electoral legislation, they do not explain the failure of the Armenian authorities to adopt other laws conditioned by EU funding. For example, the aforementioned legislation on domestic violence was not only supported by the EU, but an 11 million euro aid package was contingent on its adoption (Abrahamyan2017). Although the authorities have vowed to organise public discussions, the withdrawal of this law in 2017 seems to indicate successful Russian diffusion.

\section{The role of legitimacy}

The logic of consequences is not confined to material utility or to the role of external sanctions and incentives. Elites may adopt norms in the absence of external pressure because they perceive an instrumental benefit in doing so, and this benefit may include increasing their own legitimacy - even if actors do not view the norms as legitimate (Wendt 1999, 271). As such, concerns over legitimacy, in particular at the elite level, form part of the logic of consequences and have been used to explain the adoption and rejection of international norms in other contexts (Acharya 2004, 248; Katsumata 2011; Klotz 1999, 27). As argued in this article, in addition to material incentives, legitimacy is a key contextual variable that explains the policy choices of the Armenian ruling elite.

According to Freedom House, Armenia's democracy rating has been remarkable consistent in the period 2008-2017, but this belies persistent corruption problems and an oligarchic clan system that has gradually consolidated its hold over the political system, leading some to classify Armenia as a 'semi-autocratic' regime (Chryssogelos 2017, 269). ${ }^{\text {vi }}$ Importantly, the legitimacy of the ruling group has weakened considerably following the 2008 presidential election, when power was passed within the 'Karabakh clan', from Robert Kochyran to Serzh Sargsyan.

The 2008 presidential election was considered fraudulent by supporters of second placed candidate, Levon Ter-Petrosyan - Armenia's first president - and mass protests followed. On 
March 1, police moved to disperse demonstrators resulting in over 100 arrests and at least 10 fatalities (Gogia 2009).

March $1^{\text {st }} 2008$ was probably a turning point in terms of the internal political situation. In 2008 there were taboos that were broken. It was the first time that there were victims of clashes with the police and that protesters were killed. Before that nobody would ever think that authorities would shoot demonstrators (Interview, Aram Manukyan, 2014).

Opinion polls reveal the extent of the legitimacy crisis for the ruling group since 2008. For all key institutions of governance, including parliament, parties, executive power, the courts and the media, there has been a steep and consistent drop in levels of trust among the public. For example, opinion polls show that levels of trust in the president dropped from 53 per cent in 2008 to 16 per cent in 2015 (Caucasusbarometer 2015). Moreover, the percentage of respondents who thought that national politics was heading in the right direction dropped from 31 per cent to just 7 per cent in the same period (Caucasusbarometer 2015). As one interviewee noted:

There is no trust in the government and there is no trust in the opposition either', meaning that political dissatisfaction is more likely to get channelled through 'extraordinary means', as seen in the civil unrest surrounding the events in July 2016 (Interview, Mark Grigoryan, 2016).

As such, and with single digit approval for domestic politics, the search for legitimacy in a semi-authoritarian regime, like Armenia's, has influenced attitudes toward the NGO sector. The role of NGOs in Armenian society and the political system is complex and at times contradictory. Estimations of the Armenian NGO sector are not always positive (Loda 2016; Paturyan and Gevorgyan 2014) and opinion polls show consistently low trust ratings for NGOs (22 per cent in 2015), but still higher than political parties and parliament ( 9 per cent and 11 per cent in 2015 respectively, Caucasusbarometer 2015). In particular, NGOs often have a negative stereotype as 'grant eaters' - organisations that take money but which have little positive impact on the lives of ordinary people.

However, there is also a suggestion that the NGO sector is becoming more important due to the nuances of the political system, and that NGOs offer better platforms for talented young people to affect political life - more so than political parties, in particular opposition parties. Although NGOs by definition do not possess political power, they do retain influence and enjoy other advantages, 'NGOs are influential because they are financed by the West and 
have hardly any pressure on them; a person is much freer than in a political party' (Interview Daniel Ionesyan, 2016).

There is also a suggestion that the government uses NGOs to boost the legitimacy of key policy in the eyes of domestic and international audiences. A positive assessment from civil society on important legislation, for example, is more likely to enhance popular estimations of the political system but also secure continued funding from Western donors, 'They can go to the EU and say 'look, civil society is ok with this, so give us the money'. They can't go to fake NGOs, they have to go to real NGOs' (Interview, David Armeniyan, 2016).

This use of NGOs if often in tandem with compliant 'opposition parties' which act as intermediaries with civil society to confer legitimacy on political processes within the country. This process was seen clearly in the drafting of the new electoral code, in which NGOs played an unusually prominent role. The draft legislation was drawn up in the socalled $4+4+4$ format - four members of the ruling party, four representatives from the opposition, and four from civil society. Aside from approximately 16 million euros of funding depending on the adoption of an approved electoral code, 'part of the idea of the 4+4+4 format was to boost public trust' (Interview, Naira Zohrabyan, 2016).

In fact, there is some evidence that the authorities were keen to increase the public standing of NGOs with the new legislation that came into effect in 2017. For example, the new regulations subjecting NGOs in receipt of state funding to an external audit are less a restriction and more a measure to fight corruption and claims that fake NGOs are syphoning off state money. In 2013, it was reported that a number of NGOs had received over 1 million USD in government grants, 2011-2012, but were non-existent, with links to untraceable individuals or individuals closely connected to the ruling group (Martirosian 2013). In a similar way, Armenia's aforementioned Public Council, created in 2008, was less a means of increasing control over civil society and more a way for the ruling group to repair damaged state-society relations and to establish greater dialogue with the NGO sector following the 2008 election 'legitimacy crisis' (Borshchevskaya 2013).

The search for legitimacy also offers an explanation for the effectiveness of some of the ideas and practices emanating from Russia. As seen in the previous section, there is evidence that Russia has at least promoted certain restrictions on civil and political rights with a particular focus on gay rights and non-traditional gender relations, in part to create a 'civilizational gulf' between the EU and new and prospective member states. In the case of Armenia, this 
has been greatly facilitated by Russian language media but also a receptive public audience. In 2011, for example, the last time the Caucasus Barometer published surveyed opinions on homosexuality, 97 per cent of respondents said that it can never be justified (Caucasus Barometer 2011). In more recent research conducted in 2015-2016, 98 per cent of respondents expressed a view that homosexuality was morally wrong, topping the list of 18 central and east European countries that included fellow Orthodox Christian Russia (85 per cent) and neighbouring Georgia (90 per cent) (Pew 2017).

In reality, Armenia's political establishment has often let issues relating to sexual minorities go unchallenged, underlining the fact that many authoritarian ideas and practices are already well-established in the post-Soviet space. In October 2016, during a parliamentary discussion on the possibility of a laxer NGO law, a member of the ruling Republican Party objected, stating that the result would be 'gay parades on our streets' (Epress.am 2016b). In a more serious incident in 2012, two opposition politicians condoned the fire-bombing of a gayfriendly bar in Yerevan, stating that it was in line with 'the context of societal and national ideology', while the parliamentary vice-speaker and spokesperson for the Republican Party told a newspaper that the attack was 'completely right and justified' (Amnesty 2012).

\section{Conclusions}

This article contributes to existing literature on the international dimensions of authoritarianism by addressing the 'agency deficit' and by considering evidence of authoritarian diffusion but also the circumstances under which linkage and leverage are translated (or not) into policy convergence. In the case of Armenia, 2013-2017, there is evidence of authoritarian diffusion, but limited evidence of policy convergence in key areas, such as NGO and electoral legislation - despite the opportunity of major amendments. Based on the previous discussion, there are three concluding observations to make regarding policy, the mechanisms behind authoritarian diffusion and future research avenues respectively.

First, and in terms of policy suggestions, there is a clear relationship between authoritarian diffusion and democratic diffusion. As argued in this article, material incentives and concerns over legitimacy continue to privilege democratic norms and to make the costs of Russianstyle restrictive legislation prohibitive for incumbents. The implication is that, despite the limited embeddedness of democratic norms in much of the post-Soviet space, including Armenia, democracy promotion is effective in countering authoritarian diffusion, meaning continued Western support for democracy is essential for halting the regional and global 
trend of declining political rights and civil liberties. Although Russia is not regarded as a 'credible source of policy templates for modernisation' in many countries, including Armenia (Delcour and Wolczuk 2015, 502), this may change in the future, meaning that Russianinspired authoritarian diffusion should not be underestimated.

Second, and in terms of mechanisms, diffusion is not the only explanation for the persistence of authoritarianism in the post-Soviet space nor the only way Russia contributes to negative democratic trends in the region. Russian influence seems to create a 'zone of permissiveness' where states are able to ignore their democratic commitments, with the support of Moscow, even if no diffusion is evident. In this sense, part of Russia's attractiveness in the region is premised on what Wilson and Popescu identify as a durable trend in the East - the desire of smaller states to retain as much sovereignty as possible and to play off the EU and Russia against each other (Wilson and Popescu 2009, 318). In the case of Armenia, Russia is permissive of both the Sargsyan regime and its desire to retain close links with the EU and US, in return for loyalty and a continuing Russian presence in the South Caucasus.

The final observation relates to avenues for future research. In line with the agency deficit already mentioned, more attention should be devoted to the subject of 'localisation' and the way seemingly powerless actors have room to adopt, reject and adapt ideas and practices. While there is a general acknowledgment that small states are subject to profound systemic foreign policy constraints due to their weakness in the international system (Hey 2003, 193), small or weak states often have surprising agency to achieve their goals (Kassab 2015). Future diffusion from external actors in Armenia, but also the wider region, will likely result in 'a dynamic process of matchmaking' (Acharya 2004, 243), with the ruling elites mixing democratic and authoritarian ideas and practices in a way that fits context-specific international and domestic constraints.

\section{Appendix 1: Interviews}
Abrahamyan, Gayane
Independent journalist
Ahoranian, Lara
Director, Women's Resource Centre
Arzoumanian, Alexander
Deputy, National Assembly of Armenia (Free Democrats) 
Ayrazyan, Sona

Barseghyan, Levon

Ghazaryan, Gevorg

Giragosian, Richard

Grigoryan, Mark

Hambardzumyan, Mikael

Harutyunyan, Robert

Hoktanyan, Varuzhan

Hovannisyan, Armen

Hovhannisyan, Mikael

Hovhannisyan, Zara

Ionesyan, Daniel

Iskandaryan, Alexander

Khachatryan, Vahagn

Khachaturian, Anjela

Khadjaryan, Tigran

Krikorian, Stefan

Manukyan, Aram

Matosian, Maro

Sakunts, Artur

Shahinian, Gulnara

Shahnazaryan, David

Shahnazaryan, Gohar

Vardanyan, Aghvan

Zohrabyan, Naira
Director, Transparency International Anticorruption Center

Head, Azparez Club of Journalists, Gyumri

Independent Journalist

Director, Regional Studies Center (RSC)

Director, Public Radio of Armenia

Representative, Oxfam Armenia

Director, Armenian Development Agency

Project Director, Transparency International Anticorruption Center

Representative, Hayazn Party

Programme Manager, Civic Engagement in Local Governance

Coordinator, Coalition to Stop Violence against Women

Program Director, Union of Informed Citizens

Director, Caucasus Institute

Economist, Armenian National Council

Spokesperson, Free Democrats Party

Representative, Progressive Centrist Party

Chairman, Analytical Centre for Globalization and Cooperation

Deputy, National Assembly of Armenia (Armenian National Congress)

Executive Director, Women's Support Centre

Chairperson, Helsinki Citizens’ Assembly-Vanadzor

Project Manager, Democracy Today

Director, Soros Foundation

Director of YSU Center for Gender and Leadership Studies

Deputy, National Assembly of Armenia (Revolutionary Federation)

Leader, Prosperous Armenia Party

\section{References}


Abrahamyan, G. 2017. Armenia: Is Concern About Domestic Violence a Liberal Value? http://www.eurasianet.org/node/82331.

Acharya, A. 2004. 'How Norms Spread: Whose Norms Matter? Norm Localization and Institutional Change in Asian Regionalism'. International Organization, 58 (2): 239-275.

Ambrosio, T. 2007. 'Insulating Russia from a colour revolution: How the Kremlin resists regional democratic trends'. Democratisation, 14 (2): 232-252.

Ambrosio, T. 2008. Catching the 'Shanghai Spirit': How the Shanghai Cooperation Organization Promotes Authoritarian Norms in Central Asia, Europe-Asia Studies 60 (8) 1321-1344.

Ambrosio, T. 2010. 'Constructing a framework of authoritarian diffusion: Concepts, dynamics, and future research'. International studies perspectives, 11 (4): 375-392.

Amnesty. 2012. 'Virulent' homophobic attacks put South Caucasus activists at risk, https://www.amnesty.org/en/latest/news/2012/05/virulent-homophobic-attacks-put-south-caucasusactivists-risk/.

APR. 2017. Rodityel'skoye Vsyerossiyskoye Soprotivlyeniye (RVS) http://rvs.su/statia/roditelskoevserossiyskoe-soprotivlenie-rvs\#hcq=THAYOrq.

Areshev, A. 2013. Yevropyeyskaya Intyegratsiya dlya Armyenii: Propagandistskiye Plyoosi i Ryeal'niye Minoosi, Noev Kovcheg 15 (221, August), http://noev-kovcheg.ru/mag/201315/4031.html.

Armenianweekly. 2017. New EU-Armenia Deal Reached in Brussels, http://armenianweekly.com/2017/02/28/new-eu-armenia-deal-reached-in-brussels/.

Babayan, N. 2015. Ani-EU campaign or fight against 'gender'? http://en.aravot.am/2013/12/25/163181/

Bader, J. 2015. 'Propping up dictators? Economic cooperation from China and its impact on authoritarian persistence in party and non-party regimes'. European Journal of Political Research 54 (4): $655-672$.

Bader, J., J. Grävingholt, and A. Kästner. 2010. 'Would autocracies promote autocracy? A political economy perspective on regime-type export in regional neighbourhoods'. Contemporary Politics 16 (1): 81-100. 
Bank of Russia. 2016. Country investments and remittances.

http://www.cbr.ru/eng/statistics/?Prtid=svs.

Barkin, J. 2010. Realist constructivism: Rethinking international relations theory. Cambridge:

Cambridge University Press.

Barseghyan, L. 2016. Targeted violence against journalists in Armenia.

http://www.osce.org/odihr/272211?download=true.

Borshchevskaya, A. 2013. A Plan to Tame Civil Society in Armenia, Freedom House, https://freedomhouse.org/blog/plan-tame-civil-society-armenia.

Brinks, D. and M. Coppedge. 2006 'Diffusion Is No Illusion'. Comparative Political Studies 39 (4): 463-89.

Caucasus Barometer. 2011. Justified or not - homosexuality

http://caucasusbarometer.org/en/cb2011am/JUSHOMO/.

Cacasusbarometer. 2015. Caucasus Barometer time-series dataset Armenia, http://caucasusbarometer.org/en/cb-am/codebook/.

Checkel, J. 2001. 'Social construction and European integration in Christiansen' in The social construction of Europe edited by T. Jørgensen and A. Wiener. Sage.

Checkel, J. 2007. 'International institutions and Socialization in Europe: introduction and framework' In International institutions and socialization in Europe edited by Checkel, J. Cambridge: Cambridge University Press.

Chryssogelos, A. 2017. 'Transnational European Party Federations as EU Foreign Policy Actors: The Activities of Europarties in Eastern Partnership States'. JCMS 55 (2): 257-274.

Council of Europe. 2015. 104th Plenary Session (Venice, 23-24 October 2015) - Session report http://www.venice.coe.int/webforms/documents/?ref=CDL-PL-PV(2015)003.

Council of Europe. 2016. Armenia http://www.coe.int/en/web/programmes/armenia.

Delcour, L. and K. Wolczuk. 2015. 'The EU's Unexpected 'Ideal Neighbour'? The Perplexing Case of Armenia's Europeanisation'. Journal of European Integration 37 (4): 491-507. 
Demytrie, R. 2016. Armenians challenge age-old links to Russia, $B B C$, http://www.bbc.co.uk/news/world-europe-37025532.

Eap monitoring. 2016. Propaganda: Deepening the Gap in Mutual Understanding: Monitoring of the Media of Eap Countries and Russia, http://ypc.am/wpcontent/uploads/2017/03/2016_Monitoring_Propaganda_Report_ENG.pdf.

Epress.am. 2016a. Adoption of Domestic Violence Law in Armenia Opposed by Pro-Russian Groups: Report http://epress.am/en/2016/12/24/adoption-of-domestic-violence-law-in-armeniaopposed-by-pro-russian-groups-report.html.

Epress.am. 2016b. Discussion of New Armenian Law on NGOs Ends with Republican MPs' Homophobic Rants and 'Jokes'http://epress.am/en/2016/10/06/discussion-of-new-armenian-law-onngos-ends-with-republican-mps-homophobic-rants-and-\%E2\%80\%98jokes\%E2\%80\%99.html.

Finkel, E., and Y. Brudny. 2012. Russia and the colour revolutions. Democratization 19 (1): 15-36.

Freedom House. 2017. Freedom in the World https://freedomhouse.org/report/fiw-2017-tablecountry-scores.

Freedom House. 2017. Populists and Autocrats: The Dual Threat to Global Democracy, https://freedomhouse.org/report/freedom-world/freedom-world-2017\#anchor-one.

Gel'man, V. and Lankina, T. 2008. Authoritarian Versus Democratic Diffusions: Explaining Institutional Choices in Russia’s Local Government, Post-Soviet Affairs 24 (1): 40-62.

German, T. 2012. Regional Cooperation in the South Caucasus: Good Neighbours or Distant Relatives? Farnham: Ashgate.

Ghahriyan, H. 2014 Putin's Wit Works Woe in Armenia http://www.lragir.am/index/eng/0/comments/view/31825.

Giragosyan, R. 2013. 'The Eurasian Union: A View from Armenia'. Caucasus Analytical Digest 11: $51-52$.

Gogia, G. 2009. Democracy on Rocky Ground: Armenia's Disputed 2008 Presidential Election, PostElection Violence, and the One-Sided Pursuit of Accountability, https://www.hrw.org/report/2009/02/25/democracy-rocky-ground/armenias-disputed-2008presidential-election-post-election. 
Green, A. and R. Kohl. 2007. Challenges of Evaluating Democracy Assistance: Perspectives from the Donor Side, Democratization, 14 (1): 151-165.

Grigoryan, M. 2015. Armenia: Is Yerevan Doing the Kremlin's Bidding to "Neutralize" NGOs? Eurasianet.org http://www.eurasianet.org/node/72401.

Hale, H. 2015. Patronal Politics. Cambridge University Press: New York.

Henderson, S. 2010. 'Shaping Civic Advocacy: International and Domestic Policies toward Russia's NGO Sector. Advocacy Organizations and Collective Action' in Advocacy organizations and collective action, edited by A. Prakash and M, Gugerty. Cambridge: Cambridge University Press.

Hey, J. 2003. 'Refining our understanding of small state foreign policy' in Small states in world politics: explaining foreign policy behavior edited by J. Hey. Lynne Rienner Publishers.

Ioannisyan, D. 2016. Excessive Police violence during peaceful protests of July 2016 in Armenia, http://www.osce.org/odihr/272201?download=true.

Ishkanian, A. 2016. From civil disobedience to armed violence: political developments in Armenia. openDemocracy. https://www.opendemocracy.net/od-russia/armine-ishkanian/from-civildisobedience-to-armed-violence-political-developments-in-armen.

Jackson, N. 2010. 'The role of external factors in advancing non-liberal democratic forms of political rule: A case study of Russia's influence on Central Asian regimes'. Contemporary Politics 16 (1): 101-118.

Kassab, H. 2015. Weak States in International Relations Theory: The Cases of Armenia, St. Kitts and Nevis, Lebanon, and Cambodia. Springer.

Katsumata, H. 2011. 'Mimetic adoption and norm diffusion: 'Western' security cooperation in Southeast Asia?' Review of International Studies 37 (2): 557-576.

Klotz, A. 1999. Norms in international relations: The struggle against apartheid. Cornell University Press.

Koesel, K. and V. Bunce. 2013. 'Diffusion-proofing: Russian and Chinese responses to waves of popular mobilizations against authoritarian rulers'. Perspectives on Politics 11 (03): 753-768.

Levitsky, S. and L. Way. 2010. Competitive authoritarianism: Hybrid regimes after the cold war. Cambridge: Cambridge University Press. 
Loda, C. 2017. 'The European Union as a normative power: the case of Armenia'. East European Politics 33 (2): 275-290.

Lough, J, O, Lutsevych., P. Pomerantsev., S, Secrieru., and A. Shekhovtsov. 2014. Russian influence abroad: Non-state actors and propaganda. Chatham House, 24. https://www.chathamhouse.org/sites/files/chathamhouse/field/field_document/20141024RussianInflu enceAbroad.pdf.

March, J. and J. Olsen. 1989. Rediscovering institutions: The organizational basis of politics. New York: The Free Press.

Martirosian, A. 2013. Mysterious NGOs Benefit from Armenian Government's Largesse, https://www.rferl.org/a/mysterious-ngos-armenia-government-largesse/24973068.html.

Martirosyan, S. 2013. The 'Gender Equality Law' Hysteria in Armenia, The Armenian Weekly http://armenianweekly.com/2013/09/20/the-gender-equality-law-hysteria-in-armenia/.

Minasian, S. 2005. EU-Armenia Cooperation and the New European Neighborhood Policy. Political Reform Process in Georgia, Armenia and Azerbaijan: Political Elite and Voices of the People. CIPDD-International IDEA, Tbilisi, available at http://www. idea. int/-europe_cis/upload/EUArmenia\% 20cooperation-3. pdf.

Mkrtchyan, H. 2015. Russia grants \$200 million loan to Armenia to help modernise army, Reuters, http://uk.reuters.com/article/uk-armenia-russia-loan-idUKKCNOPC1PY20150702.

Nikoghosyan, A. 2016. In Armenia, gender is geopolitical, openDemocracy https://www.opendemocracy.net/od-russia/anna-nikoghosyan/in-armenia-gender-is-geopolitical. Novikova, G. 2017. 'Armenia: some features of internal (in) stability'. Caucasus Survey 5 (2): 177 194.

Novosti Armenia. 2016. Otkritoye obrashshyeniye k armyanskomoo narodoo i vlastyam Armyenii http://armenia-news.livejournal.com/14674.html.

Olsen, J. 2002. 'The many faces of Europeanization'. JCMS 40 (5): 921-952.

Paturyan, Y. and V. Gevorgyan. 2014. Armenian Civil Society after 20 Years of Transition: Still Postcommunist? Yerevan: Turpanjian Center for Policy Analysis; American University of Armenia. 
Pevehouse, J. 2002. 'Democracy from the Outside-In?-International Organizations and Democratization'. International Organization. 56 (3): 515-549.

Pew. 2017. Religious Belief and National Belonging in Central and Eastern Europe, Pew Research Center, http://www.pewforum.org/2017/05/10/religious-belief-and-national-belonging-in-centraland-eastern-europe/pf_17-05-10_centraleasterneurope_homosexuality420px/.

RFE/RL. 2016. Armenia to Join Russian-Led Customs Union https://www.rferl.org/a/armeniacustoms-union/25094560.html.

RIA Novosti. 2015. Kosachyev: na Kavkazye Azyerbayjan yavlyayetsya vazhnyeyshim partnyerom Rossii, https://ria.ru/politics/20150226/1049801508.html.

Roberts, S. 2015. 'Converging party systems in Russia and Central Asia: A case of authoritarian norm diffusion?'. Communist and Post-Communist Studies, 48 (2): 147-157.

Romanova, T. 2016. 'Russian Challenge to the EU's Normative Power: Change and Continuity'. Europe-Asia Studies, 68 (3): 371-390.

Sakunts, A. 2016. Tendencies to restrict the areas of civil society activity in the republic of Armenia, Side Event at the OSCE ODIHR HDIM 2016 http://www.osce.org/odihr/272186?download=true.

Sanamyan, E. 2016. April 2016 war in Karabakh: a chronology http://yandunts.blogspot.co.uk/2016/04/april-2016-war-in-karabakh-chronology.html.

Sasse, G. 2013. 'Linkages and the promotion of democracy: the EU's eastern neighbourhood'. Democratization 20 (4): 553-591.

Skene. C. 2003 Authoritarian practices in new democracies, Journal of Contemporary Asia 33 (2): 189-214.

Smith, K. 2005. 'The outsiders: the European neighbourhood policy'. International Affairs 81: 757773.

Sputnik Armenia. 2016. Tsvyetniye ryevolyootsii: Armyeniya i Kirgizstan ishshoot "antiviroos" https://ru.armeniasputnik.am/politics/20161209/5737566/cvetnye-revolyucii-armeniya-i-kyrgyzstanishchut-antivirus.html.

Tacis. 2003. National Indicative Programme for Armenia 2004-2006 http://eeas.europa.eu/archives/docs/armenia/csp/nip_04_06_en.pdf. 
Tansey, O. 2016. The International Politics of Authoritarian Rule. Oxford: Oxford University Press.

Tolstrup, J. 2013. 'When can external actors influence democratization? Leverage, linkages, and gatekeeper elites’ Democratization 20 (4): 716-742.

Tolstrup, J. 2015a. 'The problems in studying the international dimension of authoritarianism'. APSA Comparative Democratization Newsletter 13 (1): 1-11.

Tolstrup, J. 2015b. 'Black knights and elections in authoritarian regimes: Why and how Russia supports authoritarian incumbents in post-Soviet states'. European Journal of Political Research 54 (4): 673-690.

Vachudova, M. 2005. Europe undivided: democracy, leverage, and integration after communism. Oxford: Oxford University Press.

Vardanyan, G. 2017. Armenia in Russia's Zone of Influence 2017 https://www.chaikhana.org/en/armenia-in-russias-zone-of-influence.

Vasilyan, S. 2017. “"Swinging on a Pendulum” Armenia in the Eurasian Economic Union and With the European Union'. Problems of Post-Communism 64 (1): 32-46.

Vásquez, I., and T. Porčnik. 2015. The Human Freedom Index: A Global Measurement of Personal, Civil, and Economic Freedom. Fraser Institute.

Volynkin, I. 2014. Rossijsko-armjanskie otnoshenija nahodjatsja na besprecedentno vysokom urovne, Noev Kovcheg 8 (238) http://noev-kovcheg.ru/mag/2014-08/4466.html.

Von Soest, C. 2015. 'Democracy prevention: The international collaboration of authoritarian regimes' European Journal of Political Research 54: 623-638.

Wendt, A. 1999. Social theory of international politics. Cambridge: Cambridge University Press.

Wilson, A., and N. Popescu. 2009. 'Russian and European neighbourhood policies compared'. Southeast European and Black Sea Studies 9 (3): 317-331.

World Bank. 2015. Armenia remittances, http://data.worldbank.org/indicator/BX.TRF.PWKR.DT.GD.ZS?locations=AM\&page=4 .

Yakouchyk, K. 2016. 'The good, the bad, and the ambitious: democracy and autocracy promoters competing in Belarus'. European Political Science Review 8 (02): 195-224. 
Zolyan, M. 2016. The standoff in Yerevan, Open Democracy, https://www.opendemocracy.net/odrussia/mikayel-zolyan/standoff-in-yerevan.

\section{Notes}

\footnotetext{
${ }^{\mathrm{i}}$ A total of 67 countries suffered net declines in political rights and civil liberties in 2016, compared with 36 registering gains.

ii A sample of experts, party politicians and NGOs was created prior to the two field trips in 2014 and 2016, although referential sampling proved effective. Overall, the respondents' impressions and views of the political situation in Armenia, and Russia's influence were essential in researching this difficult topic. All interviews were conducted in Yerevan, unless stated otherwise.

iii These are estimates. For more detail on the extent of casualties on both sides see Sanamyan (2016).

${ }^{\text {iv }}$ Daredevils of Sassoun is the tile of an Armenian poem dating back to the eighth century and documenting the struggle to drive Arab invaders from Armenia.

${ }^{v}$ For an example of homophobic, anti-Western, Russian-language propaganda see Areshev (2013).
} 